\title{
2D Geo-electrical Resistivity Imaging of Clay Deposit in Agbonmwoba Village, Edo State, Nigeria
}

\author{
Wasiu .O. Osisanya ${ }^{1^{*}} \quad$ Abolarin .O. Macpaul ${ }^{2} \quad$ Korode A.I ${ }^{2} \quad$ Ajibade Z.F ${ }^{2}$ \\ 1.Department of Physics, University of Benin, Benin City, Edo state, Nigeria. \\ 2.Department of Petroleum Engineering and Geosciences, Petroleum Training Institute, Effurun
}

\begin{abstract}
This study involves delineation of clay deposits in Agbonmwoba village area of Obaretin town, Edo state using 2D geo-electrical resistivity tomography technique to image the extent and economic quantity of the deposit, in order to appraise its commercial viability. The Wenner-Schlumberger electrode configuration was employed in five different locations within the study area, and a total of ten (10) Wenner-Schlumberger soundings were acquired in the area with a spread length of $200 \mathrm{~m}$ along each traverse. The field data was inverted using the Earth Imager 2D inversion software program. Low resistivity geologic formations $(\rho<50 \Omega \mathrm{m})$ were interpreted as clay formations using knowledge of regional geology of the area as reported from previous studies. Along traverses 1 , 2 and 8 sampled at old Sapele road Ekiosa clay deposits was imaged at depth of 8.9-15m at lateral spread of 30m and $70 \mathrm{~m}$ in TR1, 8.9-17.9m in TR2 and $4 \mathrm{~m}$ in TR8. In traverses 3 and 4 sampled along Presco road in Obaretin, clay deposits were imaged at $8.9 \mathrm{~m}$ from the surface in TR3 and $8.9-10 \mathrm{~m}$ in TR4 at lateral spread of $70 \mathrm{~m}$ and $100 \mathrm{~m}$ respectively. Traverses 5, 6 and 7 were sampled at Agbonmwoba primary school, and clay deposit was imaged at $17.9-21 \mathrm{~m}$ in TR5 at lateral spread of $80-90 \mathrm{~m}$, clayey sand was imaged at $7.5 \mathrm{~m}(<8.9 \mathrm{~m})$ and sand deposit was imaged at $24.0 \mathrm{~m}(<26.8 \mathrm{~m})$ which underlies clay. In TR6, clay deposit was imaged at $8.9 \mathrm{~m}$ from the surface and in TR7, clay deposits were imaged in layers at profound depths $>30 \mathrm{~m}$ at lateral spreads of $20-80 \mathrm{~m}$ and $130-160 \mathrm{~m}$ respectively. In TR8 clay deposit was imaged at $4 \mathrm{~m}$ from the surface. In TR9 clay deposit was imaged at 8.9$17.9 \mathrm{~m}$ at lateral spread of $90-110 \mathrm{~m}$ and in TR 10 clay deposit was imaged at $17.9-20 \mathrm{~m}$ at lateral spread of $40 \mathrm{~m}$ and 100-120m respectively. This results show that clay deposits imaged along traverses $1,2,4,5,9$, and 10 are located at proximal depths within the subsurface and this implies that the subsurface geology distribution along these profiles is slightly homogenous in lithology, and clay deposits along these traverses are exploitable, while clay deposits along traverses 3,6 and 8 are found at the surface $(0-8.9 \mathrm{~m})$ as thin clay deposits and therefore not commercially viable for exploitation. Clay deposits imaged in traverse 7 was relatively massive in size (subsurface distribution) and was observed at profound depth of $26.8-35.7 \mathrm{~m}(>30 \mathrm{~m})$, which makes it commercially viable for exploitation compared with other traverses. The results was correlated with borehole lithologic section drilled along TR5 in the area and both sections agreed in lithologic sequence with respect to depth. Thus, 2D resistivity imaging gives a better vertical and lateral view of subsurface layers than geo-electric sections computed from 1D models, because of its ability to give a continuous record of subsurface formations at greater depth.
\end{abstract}

Keywords: Electrical resistivity tomography (ERT), Clay deposit, Wenner-Schlumberger configuration, 2D resistivity pseudosection.

DOI: $10.7176 / \mathrm{JEES} / 10-10-06$

Publication date:October $31^{\text {st }} 2020$

\section{Introduction}

Clays and clay minerals have been mined since the Stone Age; today they are among the most important minerals used by manufacturing and environmental industries. They are classified as industrial minerals. The U.S. Geological Survey (USGS) supports studies of the properties of clays, the mechanisms of clay formation, and the behaviour of clays during weathering. These studies provides evidences to how and where these minerals form and provide industry and land-planning agencies with the information necessary to decide how and where clay and clay mineral deposits can be developed safely with minimal impacts on the environment.

The characteristics common to clay minerals is derived from their chemical composition, layered structure, and size. Clay minerals have a great affinity for water. Some swell easily and expand and may double in thickness when wet. Most have the ability to soak up ions (electrically charged atoms and molecules) from a solution and release the ions later when conditions changes. The process by which some clay minerals swell when they take up water is reversible. Swelling clay expands or contracts in response to changes in environmental factors (wet and dry conditions, temperature). Lateritic clay has been reported from this region and recent studies showed this could be an important ore contributor of Bauxite (Talabi et al, 2013). Surface geophysical investigation is key in delineating the subsurface geology of an area which enables information about lithology (rock type), density, thickness and depth of subsurface formations to be deduced (Osisanya et al., 2017). The use of 2D electrical resistivity imaging to address a wide variety of environmental, hydrological and geo-technical problems is increasingly becoming very popular (Dahlin 1996 as cited by Osisanya et al., 2017).

Thus, this study aims at using surface geophysical exploration approach involving $2 \mathrm{D}$ resistivity imaging in 
investigating the subsurface lithology, identify the depth and thickness of any clay deposit encountered in the region and build $2 \mathrm{D}$ inverse model sections for the $2 \mathrm{D}$ datasets acquired in the study area.

\section{Study Area}

Obaretin is a town located in Ikpoba Okha Local government area of Edo state within the Niger Delta area of Nigeria, with geographical coordinates starting from $6^{\circ} 7.107^{\prime} \mathrm{N}$ and $5^{\circ} 39.457^{\prime} \mathrm{E}$ to $6^{\circ} 7.261^{\prime} \mathrm{N}$ and $5^{\circ} 39.748^{\prime} \mathrm{E}$. The geology of the study area is characterized by sediments deposited during the tertiary and cretaceous periods. The sedimentary rock of the study area constitutes the Benin formation which is made up of over $90 \%$ massive, coarse sand with clay/shale interbeds having a high groundwater retention capacity (Short and Stauble 1967). The topography of the area is generally flat (Akpokodje et al, 1999).

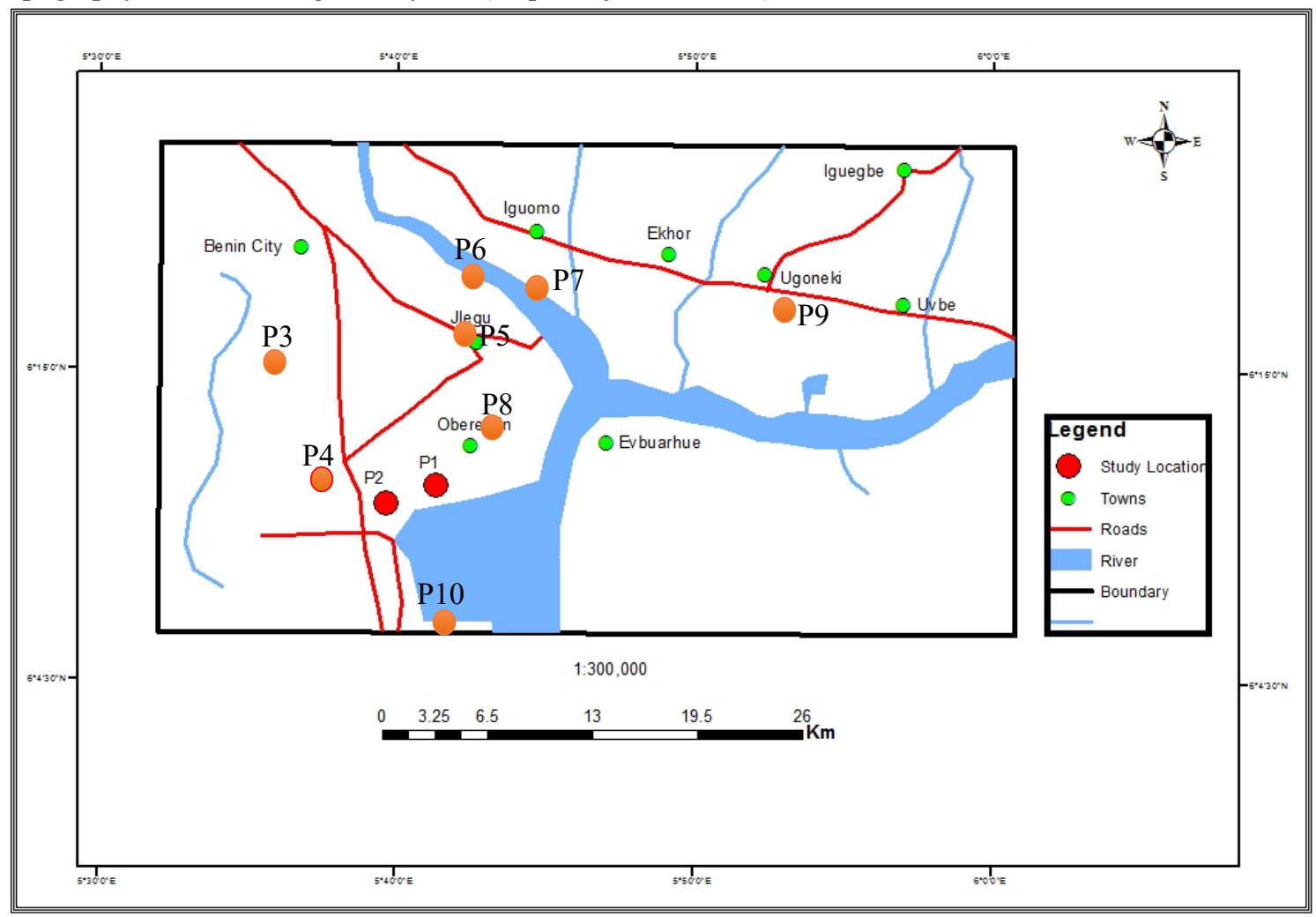

Figure 1: Base map of location showing Obaretin town and resistivity stations occupied.

\section{Method}

Ten (10) Wenner-Schlumberger soundings were acquired at five (5) different locations widely distributed in the area. The traverses TR1, TR2, and TR8 are located along old Sapele road, TR3 and TR4 are located at Presco road, while TR5, TR6, TR7 are located at Agbonmwoba primary school. In each case, ground resistivity data acquisition were made using Petrozenith Earth resistivity meter. The 2D data sets were acquired using a new array hybrid which is the Wenner-Schlumberger array geometry. This array is a new hybrid between the Wenner and Schlumberger arrays (Pazdirek and Blaha 1996), with $\mathrm{n}$ values $=(1 \ldots, 8)$ and a total profile length of $0-200 \mathrm{~m}$. The " $n$ " value of this array is the ratio of the distance between C1-P1 (or P2-C2) electrodes to the distance between $\mathrm{P} 1-\mathrm{P} 2$ potential electrodes. The median sensitivity depth of investigation for this array is about $10 \%$ greater than that for the conventional Wenner array of same distance between the C1-C2 electrodes and for " $n$ " values above 3 , hence it has a better depth coverage and higher data resolution. The ten 2D apparent resistivity data set were processed individually using 2D Earth Imager inversion software and results were presented as $2 \mathrm{D}$ resistivity depth-sections.

\section{Result and Geo-electric Sections}

Ten (10) 2D traverses well distributed in the study area were inverted using Earth Imager 2D software program. The distribution of resistivity along inverted model resistivity pseudosection gives 4 geo-electric layers identified along various profiles. The results were presented as 2D resistivity-depth sections as shown in Figures 2-11. 

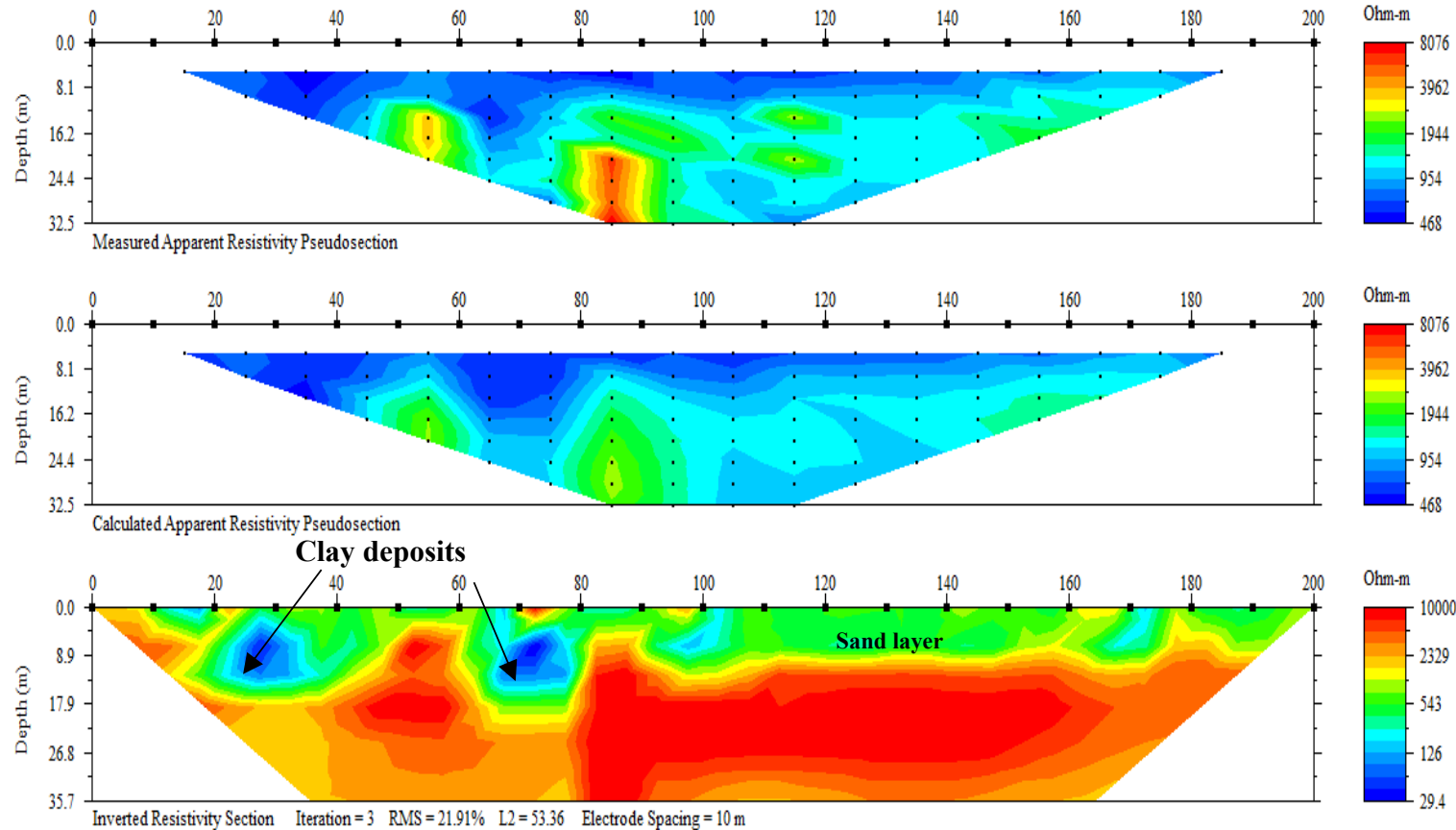

Figure 2. 2D inverse model resistivity section for profile 1.
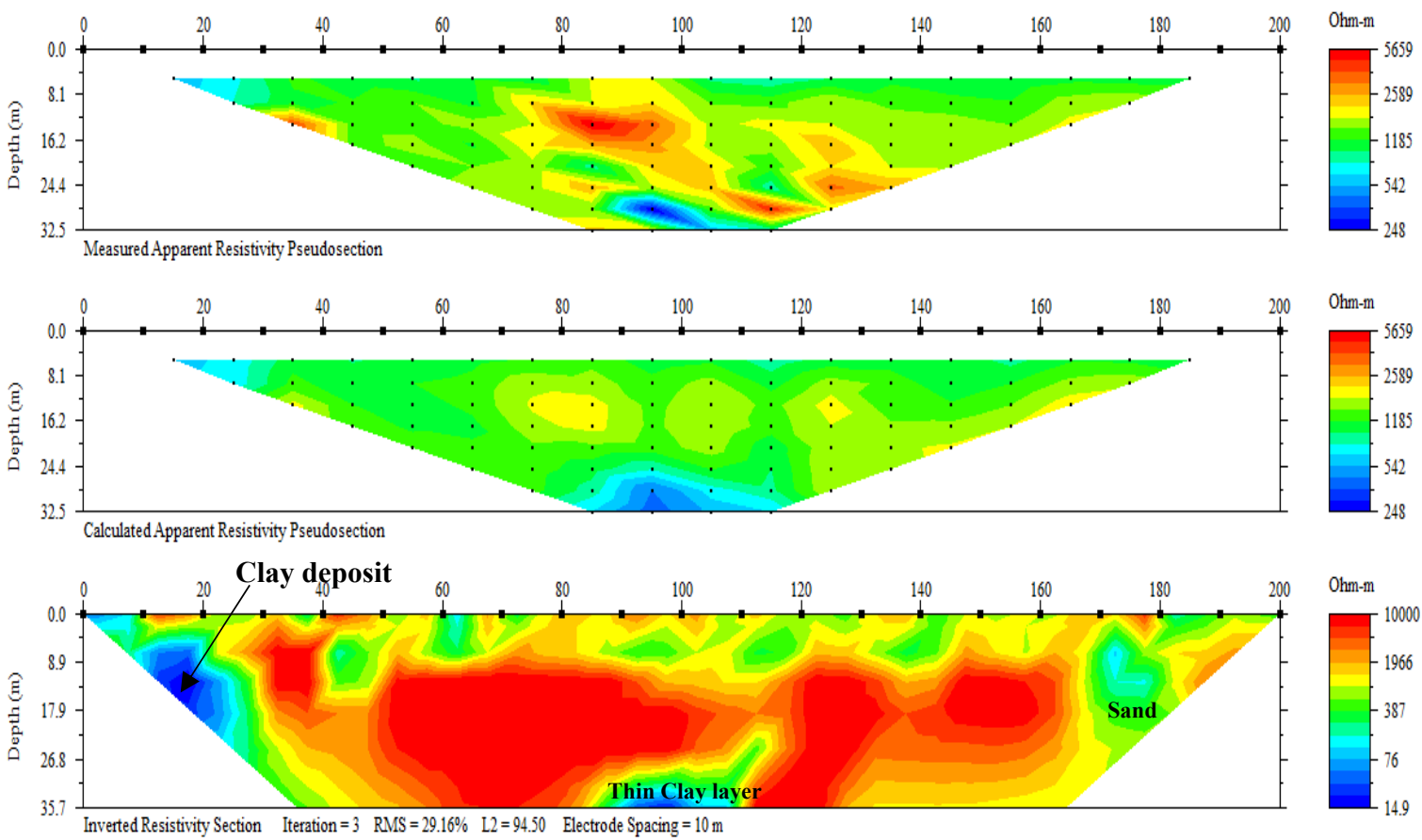

Figure 3. 2D inverse model resistivity section for profile 2 . 

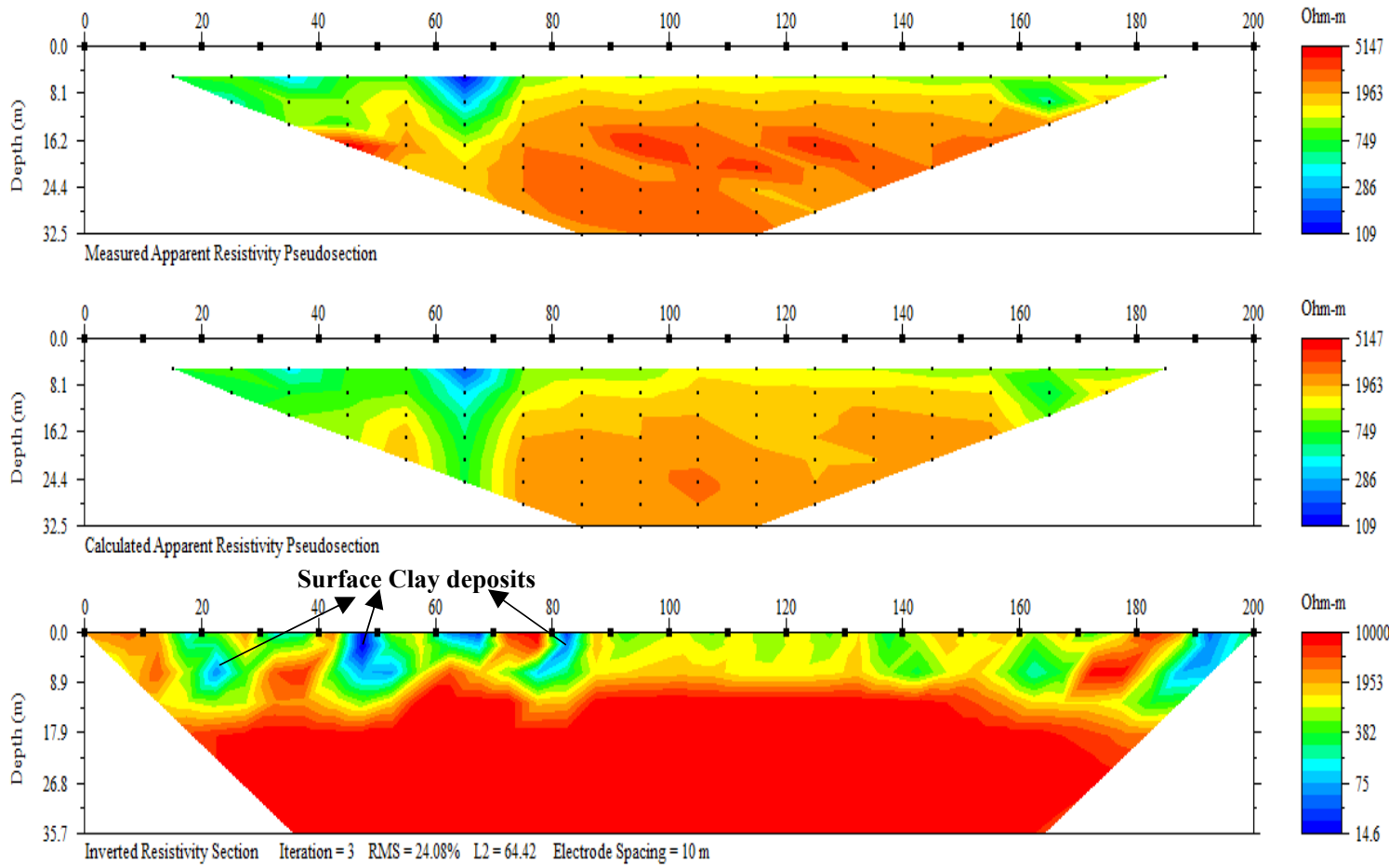

Figure 4. 2D inverse model resistivity section for profile 3.
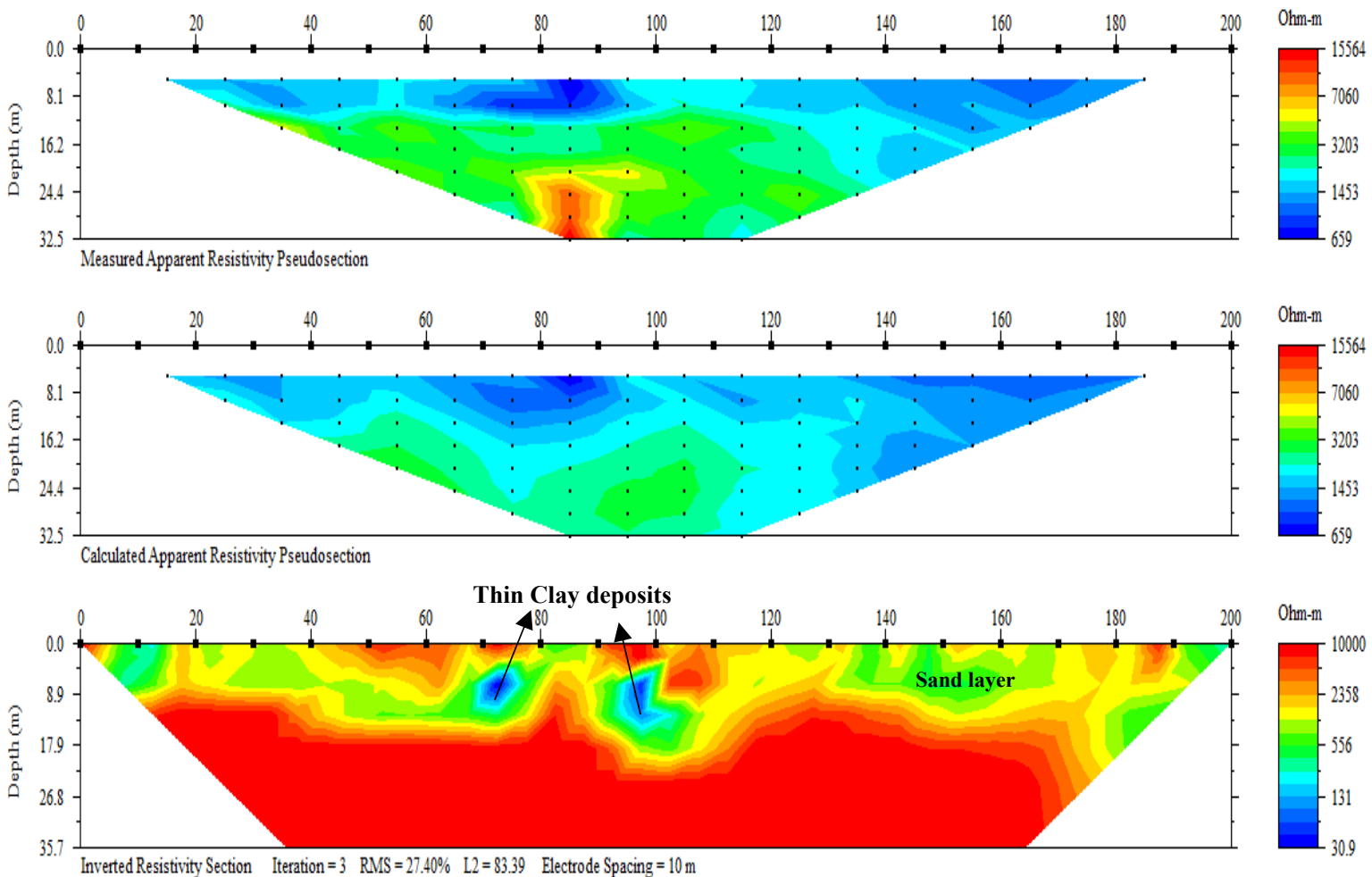

Figure 5. 2D inverse model resistivity section for profile 4 . 

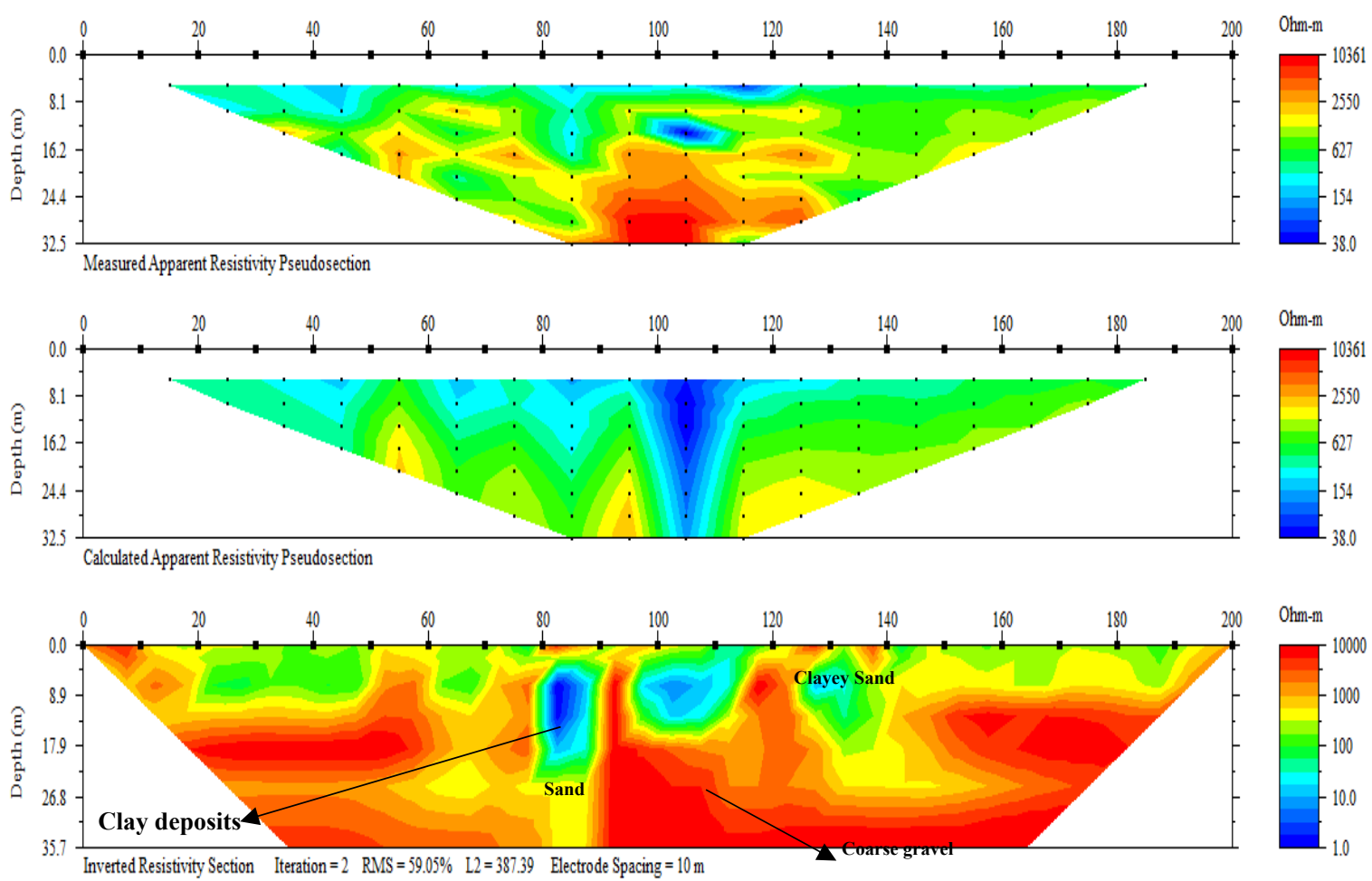

Figure 6. 2D inverse model resistivity section for profile 5.
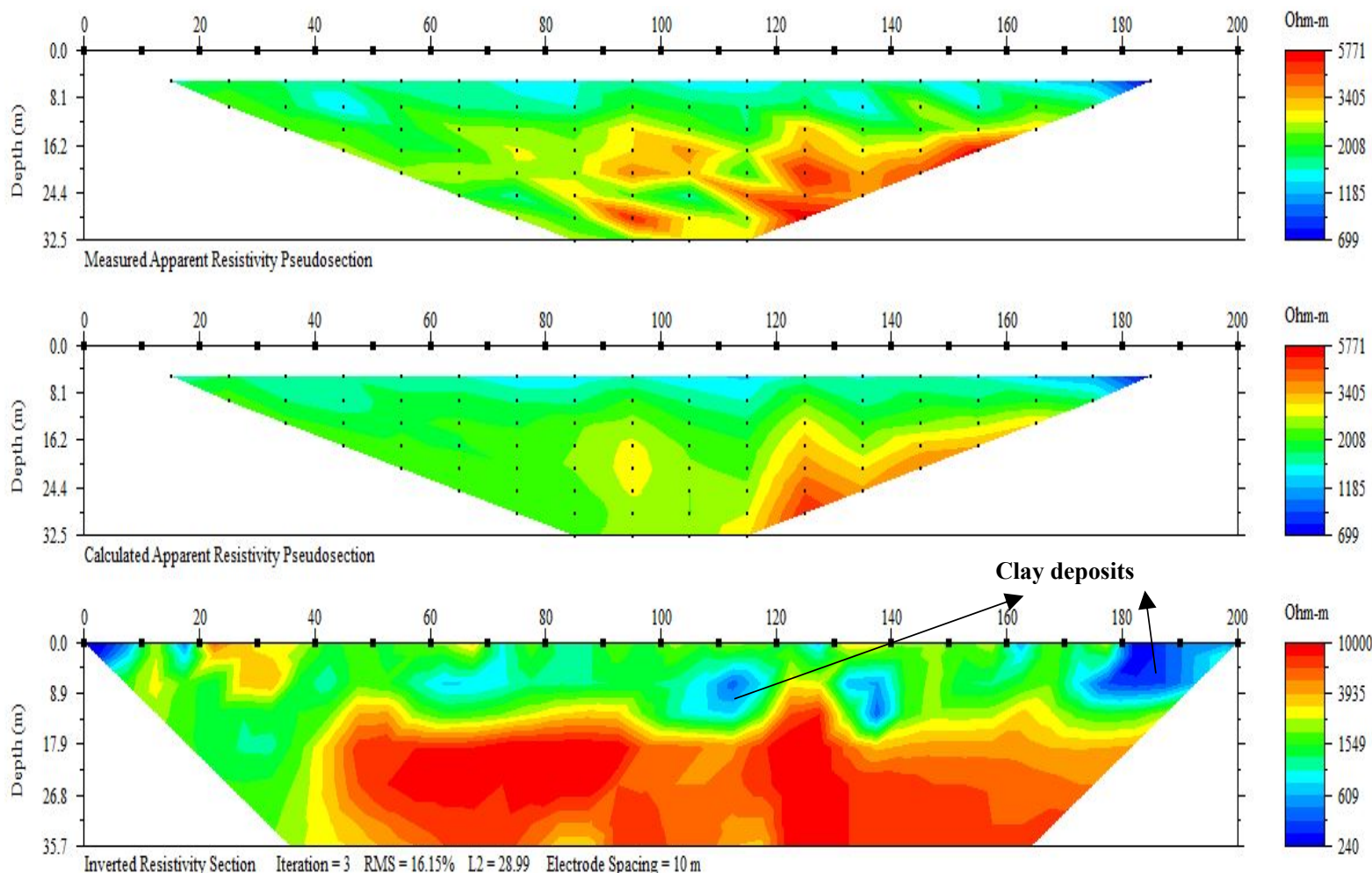

Figure 7. 2D inverse model resistivity section for profile 6. 

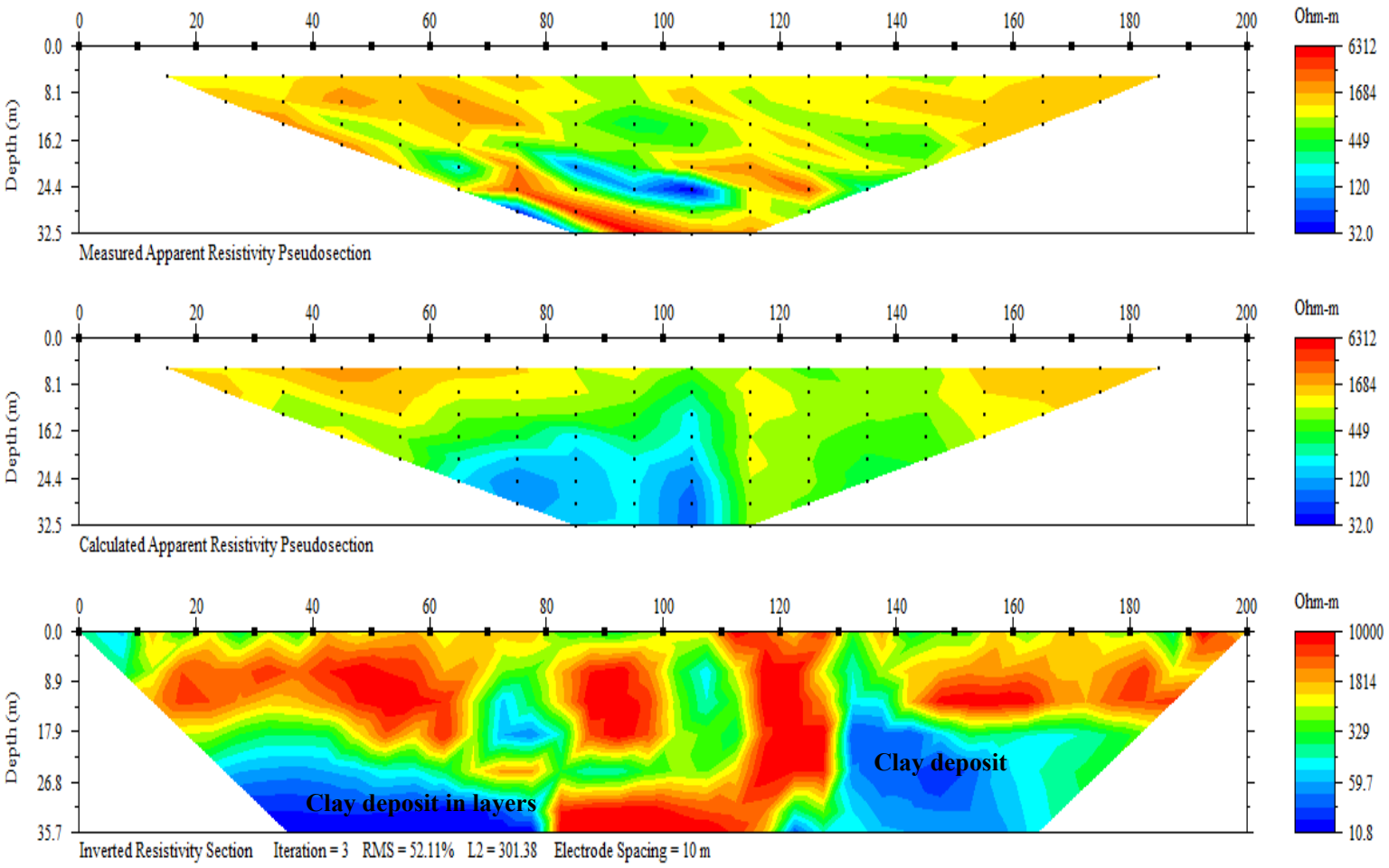

Figure 8. 2D inverse model resistivity section for profile 7
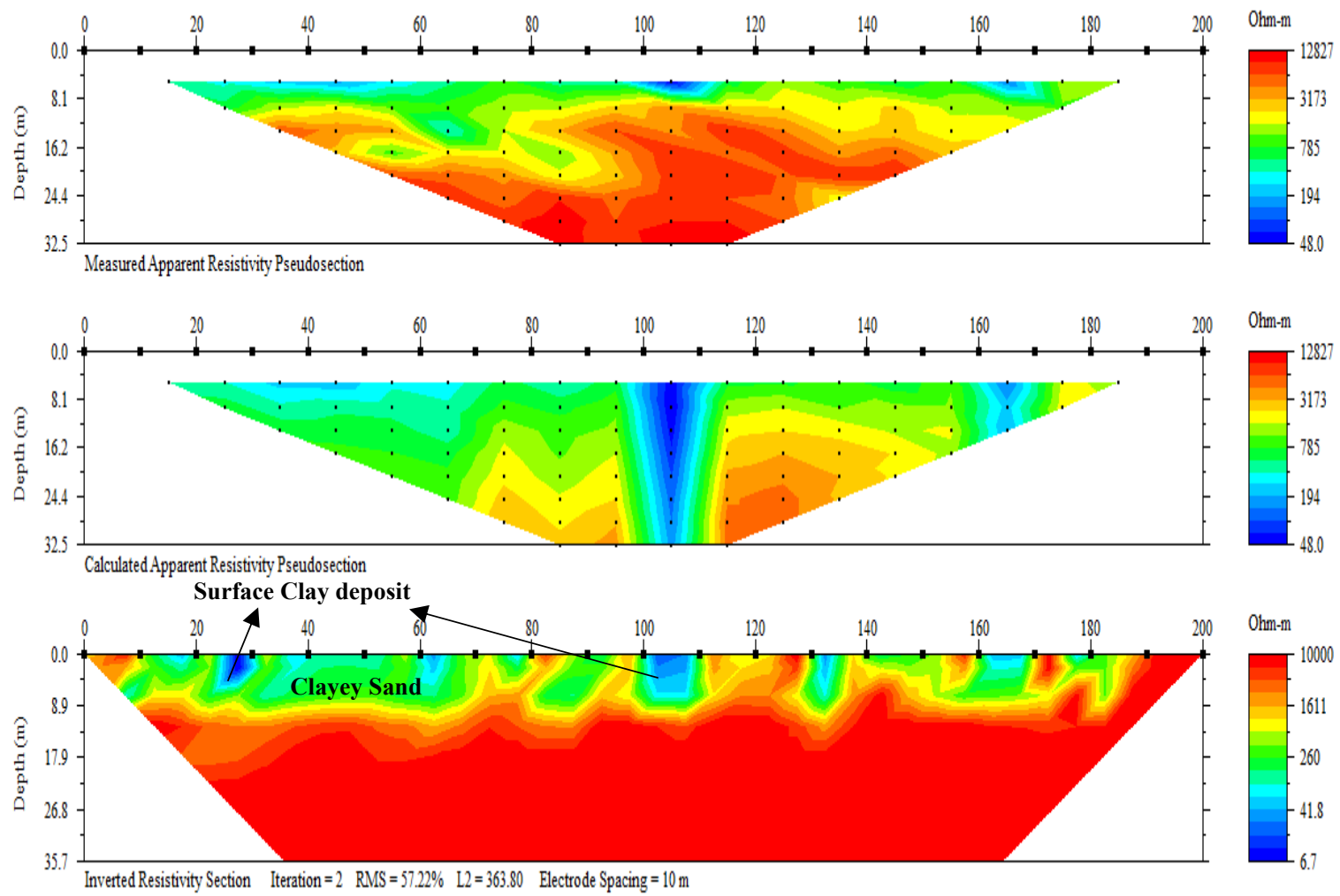

Figure 9. 2D inverse model resistivity section for profile 8 

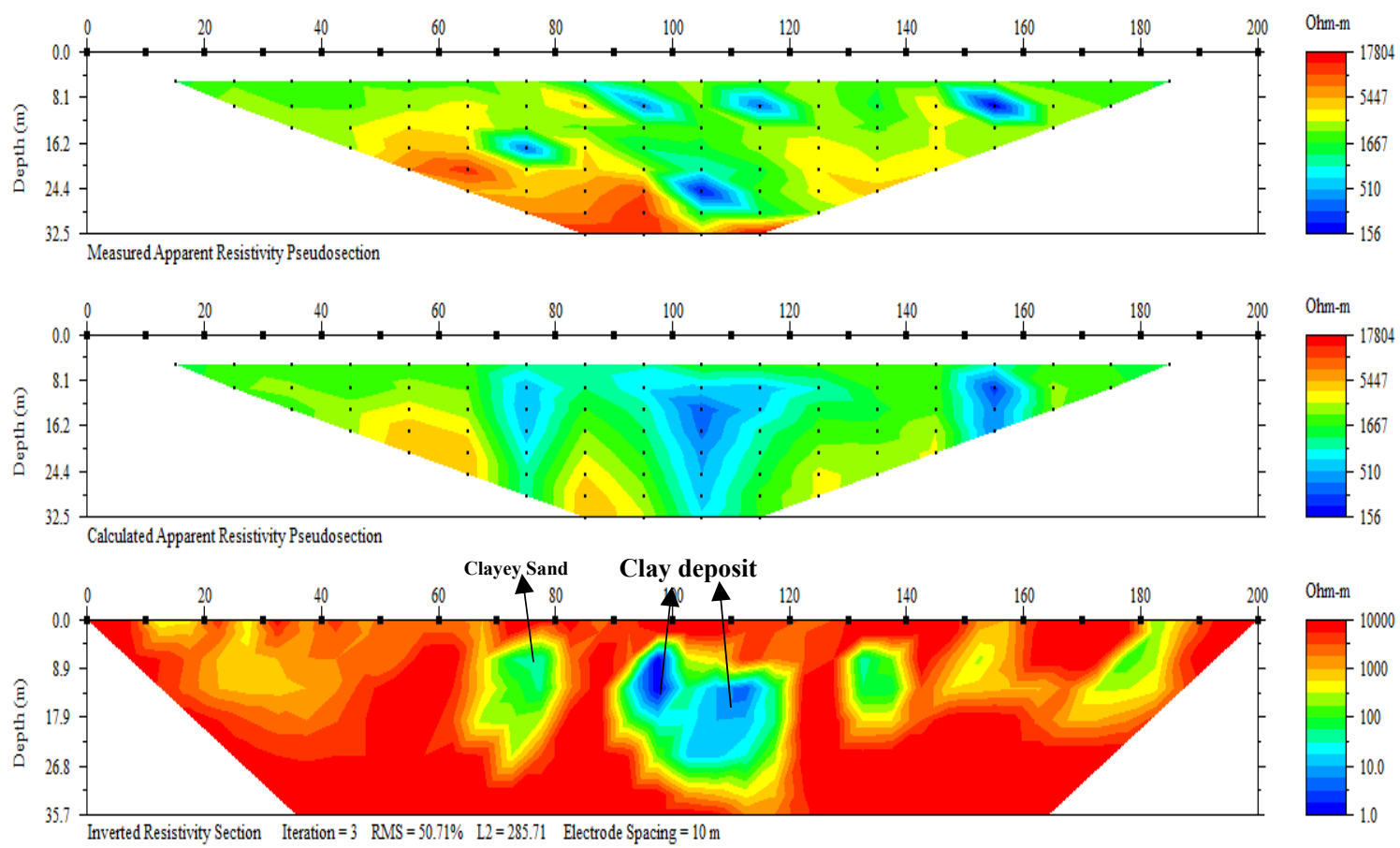

Figure 10.2D inverse model resistivity section for profile 9
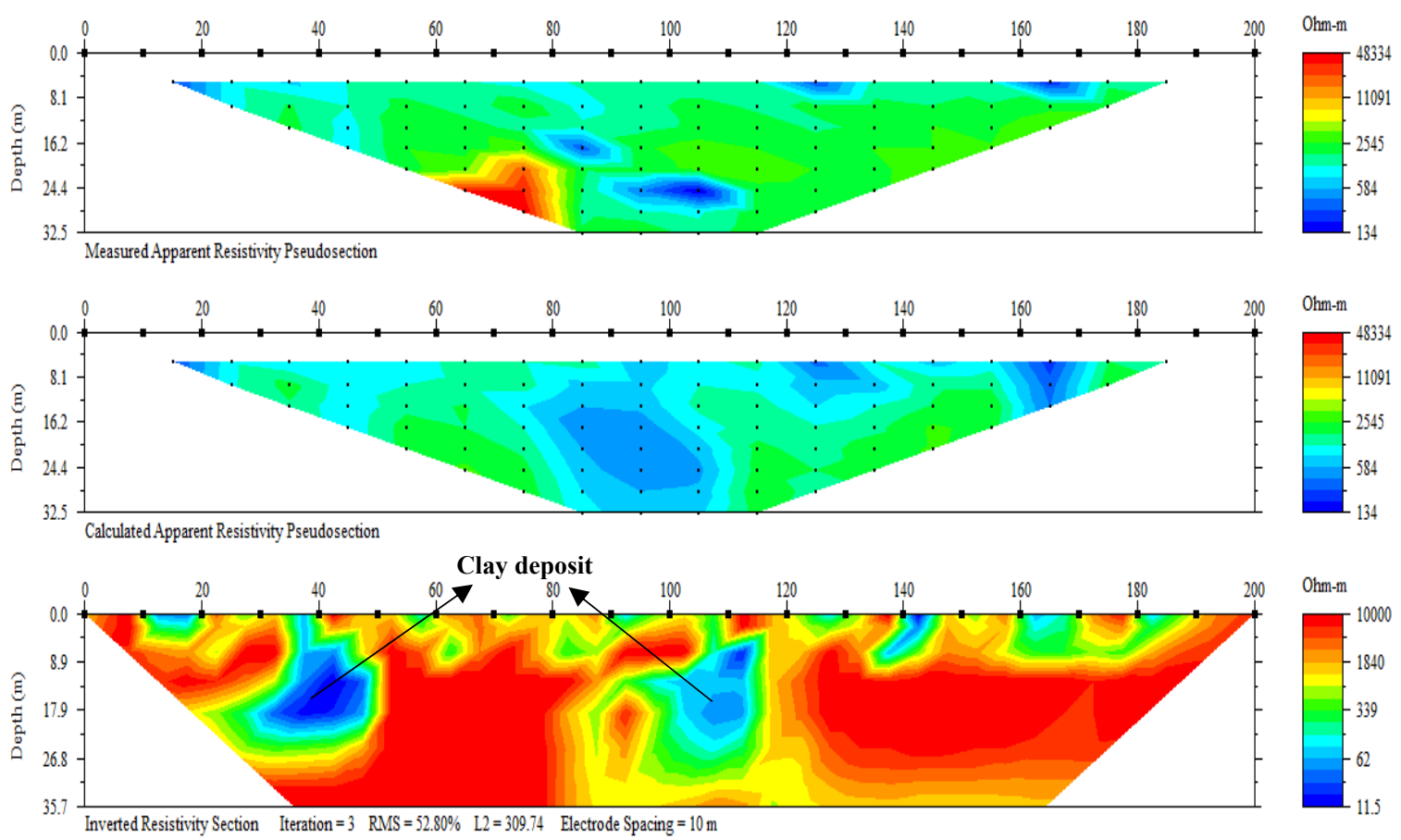

Figure 11: 2D inverse model resistivity section for profile 10

\section{DISCUSSION OF RESULTS}

2D inverted resistivity pseudosections for the ten (10) profiles are presented from Figure 2 to 11 above. For effective delineation of clay deposit in the area, resistivity values of subsurface geologic materials from selected literatures were correlated to deduce the zones of clay deposit, and its vertical and lateral extent. Low resistivity formations $(<50 \Omega \mathrm{m})$ were interpreted as clay deposits in the absence of saline sands. However, other formations

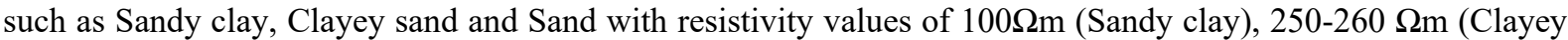
sand) and 550-1000 $\Omega \mathrm{m}$ (Sand) were also observed at some profiles. High resistivity formations of the order 8000$10,000 \Omega \mathrm{m}$ were interpreted as gravel. These resistivity interpretations were coined from existing literatures i:e (Alile et al., 2012, Ezomo et al., 2015). From the pseudo-section, the blue colour band on the inverted resistivity sections indicates clay deposit with resistivity $<50 \Omega \mathrm{m}$, while Sandy clay with resistivity value of $100 \Omega \mathrm{m}$ 
(resistivity raised by presence of sand) is seen in the light blue colour band embedded within green. Sand deposit with resistivity value of $570-1000 \Omega \mathrm{m}$ is seen on the clear green colour band and gravel deposit (red) with a resistivity range of $8000-10,000 \Omega \mathrm{m}$, is seen to underlay the various formations from profiles 1-10.

Traverses 1, 2 and 8 sampled at old Sapele road Ekiosa imaged clay deposits at depth of 8.9-15m at lateral spread of $30 \mathrm{~m}$ and $70 \mathrm{~m}$ in TR1 (Fig. 2), 8.9-17.9m in TR2 (Fig. 3), and at 4m in TR8 (Fig. 9). In traverse 2, at $35 \mathrm{~m}$ below the subsurface, a thin clay layer was also imaged. In traverses 3 and 4 sampled along Presco road in Obaretin, clay deposits were imaged at 8.9m from the surface in TR3 (Fig. 4) and 8.9-10m in TR4 (Fig. 5) at lateral spread of 70m and 100m respectively. Traverses 5, 6 and 7 were sampled at Agbonmwoba primary school. In TR5, we observed clay deposits at $17.9-21 \mathrm{~m}$ in (Fig. 6), at lateral spread of $80-90 \mathrm{~m}$, clayey sand was imaged at $7.5 \mathrm{~m}(<$ $8.9 \mathrm{~m})$ and sand deposit was imaged at $24.0 \mathrm{~m}(<26.8 \mathrm{~m})$ which underlies clay. In TR6, clay deposit was imaged at $8.9 \mathrm{~m}$ from the surface and in TR7, clay deposits were imaged in layers at profound depths $>30 \mathrm{~m}$ (Fig. 8) at lateral spreads of $20-80 \mathrm{~m}$ and $130-160 \mathrm{~m}$ respectively. In TR8 clay deposit was imaged at $4 \mathrm{~m}$ from the surface. In TR9 clay deposit was imaged at $8.9-17.9 \mathrm{~m}$ at lateral spread of $90-110 \mathrm{~m}$ (Fig 10). In TR10, clay deposit was imaged at $17.9-20 \mathrm{~m}$ at lateral spread of $40 \mathrm{~m}$ and $100-120 \mathrm{~m}$ respectively. This results show that clay deposits imaged along traverses $1,2,4,5,9$, and 10 are located at proximal depths within the subsurface and this implies that the subsurface geology distribution along these profiles is slightly homogenous in lithology, and clay deposits along these traverses are exploitable, while clay deposits along traverses 3, 6 and 8 are found at the surface $(0-8.9 \mathrm{~m})$ as thin clay deposits and therefore not commercially viable for exploitation. Clay deposits imaged in traverse 7 was relatively massive in size (subsurface distribution) and was observed at profound depth $(>30 \mathrm{~m})$, which makes it commercially viable for exploitation compared with other traverses.

\section{Comparism between Borehole Section and 2D Imaging Result along Traverse 5}

Geophysical inversion is not always uniqueness in interpretation, and one way to reduce this is the use of additional information from other sources preferably borehole data to constrain the inversion (Sudha et al., 2009). Therefore, 2D resistivity imaging along traverse 5 (TR5) was compared with a borehole section drilled along this traverse around Iyanomon area of Agbonmwoba village. The borehole section is shown in figure 12(b) below. It is observed that the depth of clay deposit imaged at this location from ERT $(17.9-21 \mathrm{~m})$ corresponded with depth obtained from borehole drilling data $(70 \mathrm{ft} \approx 21 \mathrm{~m})$ along traverse 5 and other traverses. Also the lithologic sequence from the borehole shows a sand layer overlying clay which was interpreted as Clayey sand from 2D section, and another sand layer was seen underlying clay which was also observed from the 2D section. The borehole section also shows the presence of coarse sand and coarse gravel, which was also imaged in the 2D ERT section with coarse gravel underlying the subsurface geologic formations in the area. Thus this validates the reliability of the 2D survey interpretation.
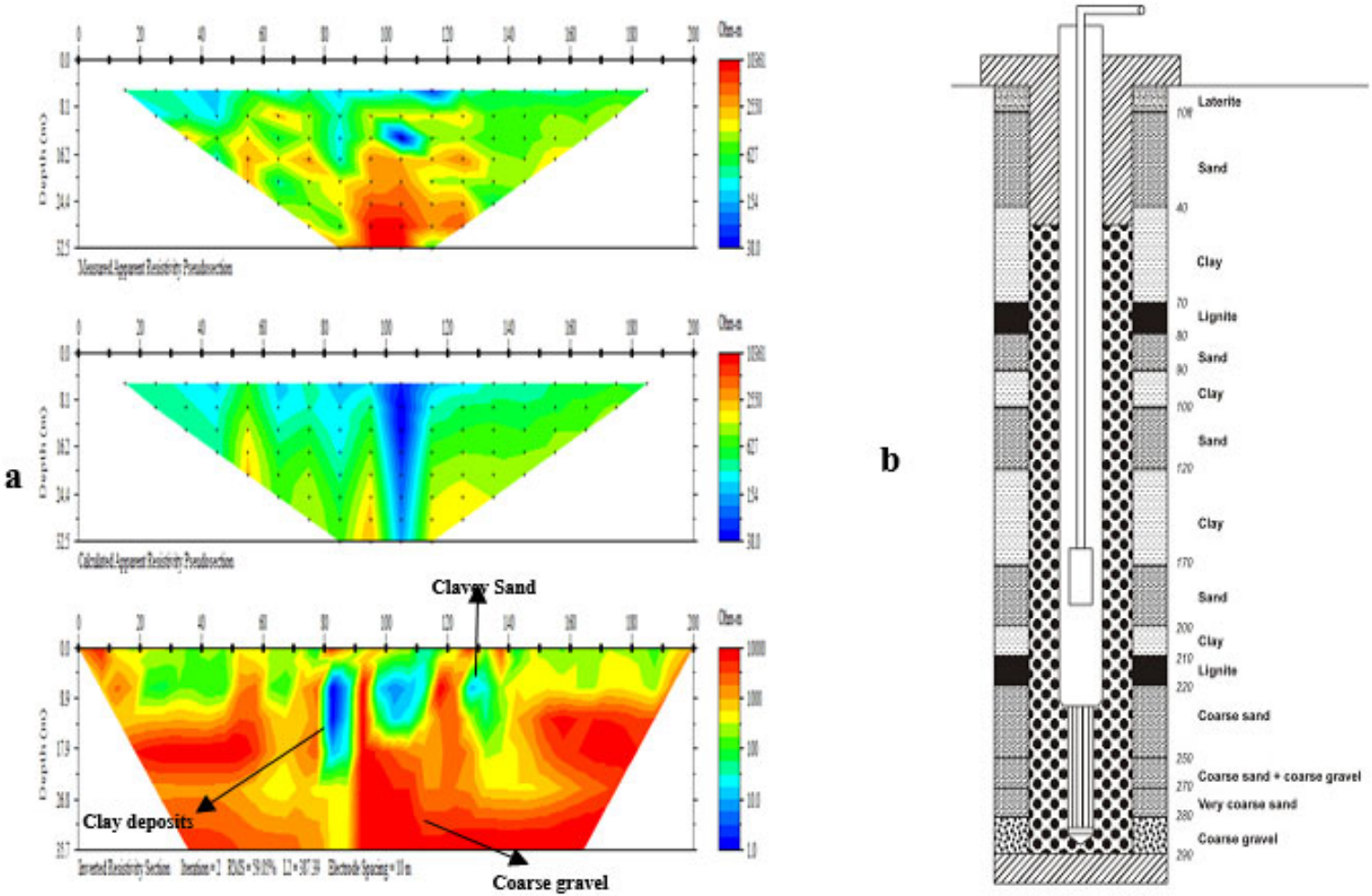

Figure 12. (a) 2D inverse model resistivity section for TR5. (b) Lithologic section of borehole drilled near Agbonmwoba primary school along TR5 (After Alile, et al., 2012). 


\section{CONCLUSIONS}

We have applied 2D ERT to delineate the vertical and lateral deposits of clay in the area, and correlated the results of the 2D resistivity tomography interpretation to borehole lithologic section in the area. This shows the sensitivity of 2D imaging technique to resolving subsurface lithologic units compared to pseudo-sections computed from 1D resistivity models. The results of the electrical resistivity imaging technique has helped to successfully delineate the depth and lateral extent of clay deposits at various locations occupied in Agbonmwoba area of Obaretin town, Benin City. Clay deposits imaged in the area generally is not in commercial quantity and is appraised to be commercially non-viable for exploitation.

\section{References}

Akpokodje, E.G., (1999). Principle of Applied and Environmental Geology. Paragraphic Publisher Port Harcourt $147 \mathrm{p}$.

Alile, O.M, Ujuanbi, O, Iyoha A (2012): Geo Electrical Investigation of Groundwater Resources at Ikpoba Okha Local Government Area, Edo State, Nigeria, Science and Technology. 2(1): 41-46.

Dahlin, T., (1996). 2D resistivity surveying for environmental and engineering applications, First Break, 14, 275284.

Ezomo F. O., Justice E.A., Ojeabu A., Ezekiel A., (2015): Delineation of Subsurface Lithology using TwoDimensional Geoelectrical Resistivity Imaging in Ologbo Area of Edo State, Nigeria. International Journal of Scientific \& Engineering Research, Volume 6, June-2015.

Osisanya, O.W, Ibitoye, A.T, Eze, S, Ezomo, F.O, and Okeh, O. (2017). Delineation of Laterite Deposits using Two-Dimensional GeoElectric Imaging in Agbonmwoba Village Area of Obaretin Town, Edo State, Nigeria, Journal of Emerging Trends in Engineering and Applied Sciences (JETEAS), 8(6): 233-243.

Pazdirek, O. and Blaha, V., (1996). Examples of resistivity imaging using ME-100 resistivity field acquisition system. EAGE 58th Conference and Technical Exhibition Extended Abstracts, Amsterdam.

Sudha, K., Israil, M., Mittal, S., \& Rai, J. (2009). Soil characterization using electrical resistivity tomography and geotechnical investigations. Journal of Applied Geophysics, Elsevier, 67, 74-79. http://dx.doi.org/10.1016/j.jappgeo.2008.09.012

Short, R.C., and Stauble A.J., (1967). Outline of Geology in the Niger Delta, AAPG V. 51 No. 5, p. 761 -779.

Talabi, A., Ademilua, O., Ajayi, O., \& Ogunniyi, S. (2013). Preliminary Geophysical Evaluation of Orin Bauxite Deposit, Southwestern Nigeria. Journal of Emerging Trend in Engineering and Applied Sciences, 4 (3), 423437. 